\title{
Using stable isotopes of water to infer wetland hydrological dynamics
}

\author{
A. Clay ${ }^{1}$, C. Bradley ${ }^{1}$, A.J. Gerrard ${ }^{1}$ and M.J. Leng ${ }^{2}$ \\ ${ }^{1}$ School of Geography, Earth and Environmental Sciences, University of Birmingham, Birmingham, B15 2TT, UK \\ ${ }^{2}$ NERC Isotope Geosciences Laboratory, British Geological Survey, Keyworth, Nottingham, NG12 5GG, UK
}

Email for corresponding author: ClayA@rpsgroup.com

\begin{abstract}
This paper considers the potential of oxygen and hydrogen isotope ratios to identify spatial and temporal changes in the water source of a lowland headwater wetland situated adjacent to the River Tern in Shropshire, UK. Stable isotope composition $\left(\delta^{18} \mathrm{O}\right)$ of end-members varied between -7.5 and $-8.0 \%$ for groundwater, -7.3 and $-8.5 \%$ for river-water and -4.5 and $-8.0 \%$ o for precipitation. Water samples were extracted from six nests each comprising three porous cup samplers at depths of $0.2 \mathrm{~m}, 0.5 \mathrm{~m}$ and $1.0 \mathrm{~m}$ between June 2000 and October 2001 , and their isotope compositions determined. Groundwater appears to be the main source of water to the wetland, but stable isotope ratios enable seasonal variations in the contribution of precipitation to be determined, and indicate the extent of precipitation storage within the wetland.
\end{abstract}

Keywords: oxygen and hydrogen isotopes, water source, hydrodynamics, lowland wetland

\section{Introduction}

Freshwater wetlands are characterised by significant temporal and spatial variations in the pattern and magnitude of water inflows and outflows. These produce distinctive water table fluctuations that reflect hydrometeorological conditions and changes in the predominant water source (Winter, 1999; Bradley, 2002). Such wetlands can be characterised by a seasonal hydrological cycle in which waters within the wetland will comprise varying quantities of water derived from precipitation, groundwater and surface-water sources. Groundwater is likely to be proportionally more important in summer when the water table is depressed by evapotranspiration while, in winter, the water table recovers as a result of higher precipitation, surface-water inflows and, for floodplain wetlands, floodwater inundation along the channel margins. Although these seasonal changes in the predominant water source may be considerable, their importance is likely to be limited by the extent to which water is redistributed through the wetland. This will reflect the wetland hydro-stratigraphy, i.e. the relative position of different sediment types, with characteristic hydraulic conductivities (Bradley, 1997; Zeeb and Hemond, 1998).

Many wetland hydrology studies have described the wetland water table or developed an annual wetland water budget (Owen, 1995; Cooper et al., 1998). Whilst this may illustrate the wider context of a wetland, and the links between wetland hydrology and ecology (Drexler et al., 1999), the water budget often fails to represent the variability in wetland hydrological processes adequately. It is important, for example, to identify periods with a low water table and a high soil moisture deficit, and differences in the relative contribution of particular water sources to total wetland storage.

Determining the stable isotope ratios of water $\left({ }^{18} \mathrm{O} /{ }^{16} \mathrm{O}\right.$, ${ }^{2} \mathrm{H} /{ }^{1} \mathrm{H}$ ) may elucidate wetland hydrological dynamics in a number of respects. Environmental isotopes in headwater wetlands have enabled the contribution to be determined of 'old' or pre-event waters to storm hydrographs (Hill and Waddington, 1993; Waddington et al., 1993). Variations in stable isotope composition can clarify patterns of groundwater recharge and flow and have been used to 


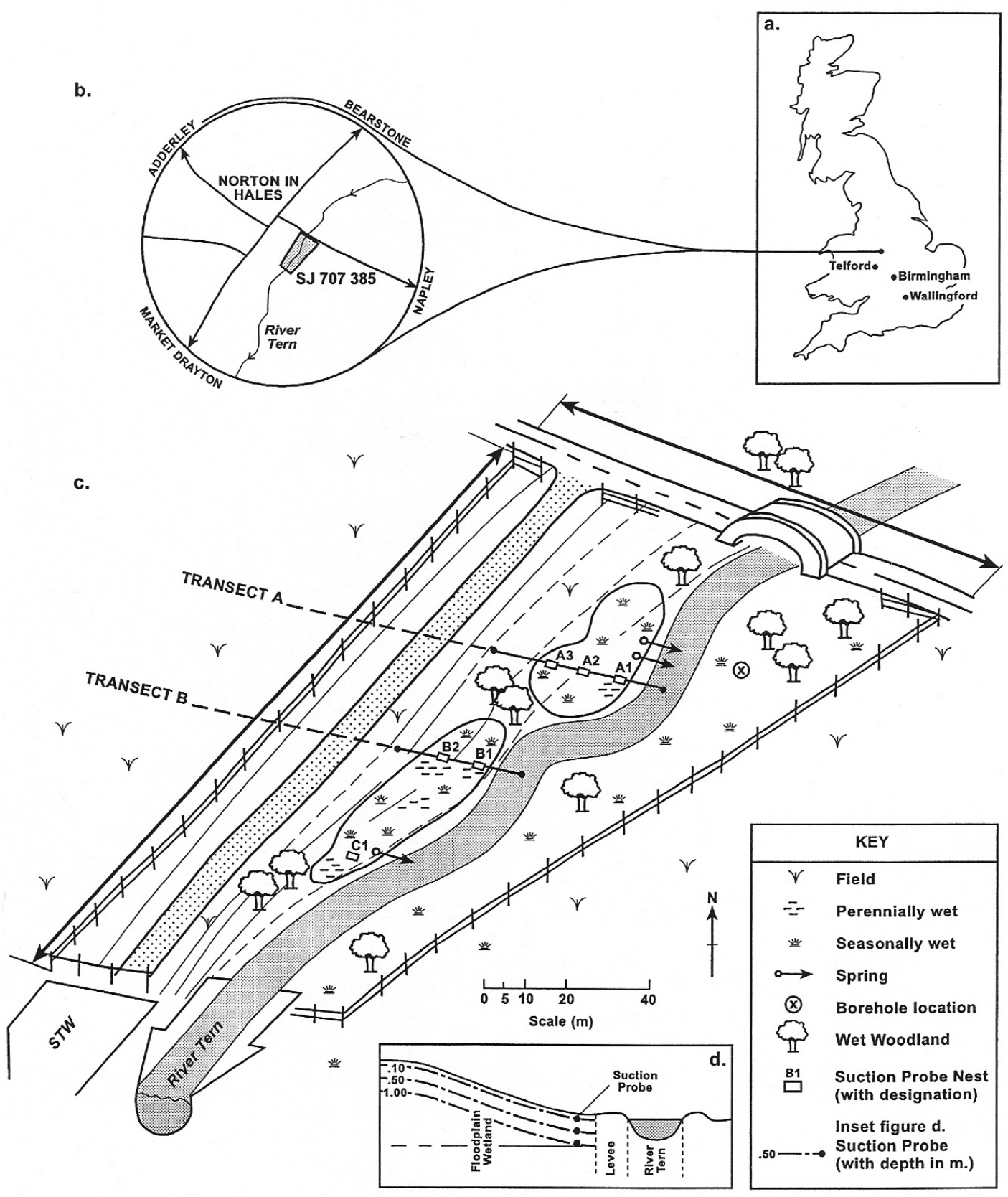

Fig. 1. Location of the study site in relation to Norton-in-Hales and Wallingford ( $a-b)$; a schematic cross-section showing the two transects (c) and locations of the porous cup samplers.

estimate groundwater residence time within valley-bottom organic deposits in an upland catchment (Soulsby et al., 2000). Stable isotopes have been used successfully to discriminate sources of groundwater recharge in a coastal wetland (Huddart et al., 1999) and to determine wetland water sources for use in mixing models (Hunt et al., 1996; 1997).

These studies demonstrate that where discrete water inflows can be characterised by distinct isotopic signatures, stable isotopes may indicate the provenance and residence time of wetland waters. However, comparatively few studies have used stable isotopes specifically to investigate the seasonal dynamics of wetland water storage. This paper reports on the use of this technique which has revealed monthly variations in the water sources of a temperate headwater wetland within a small lowland floodplain in north Shropshire, UK. Further, it has been used to characterise the composition of the various water sources (i.e. seasonally changing atmospheric deposition; surfacewater inflows that vary between individual events; and 
relatively consistent groundwater discharge) and the possibility of fingerprinting water sources by analysing the ${ }^{18} \mathrm{O} /{ }^{16} \mathrm{O}$ and ${ }^{2} \mathrm{H} /{ }^{1} \mathrm{H}$ ratios of water samples extracted from different depths over a 15 -month period have been examined. Ultimately, the isotope data are used to infer temporal changes in wetland water source. This is one of the first studies in the UK to use stable isotopes in lowland settings to elucidate the seasonal pattern of water influx and the composition of waters within a wetland.

\section{Methods}

This study was undertaken on a small headwater wetland near Norton-in-Hales c. $8 \mathrm{~km}$ from the source of the River Tern, North Shropshire ( $2^{\circ} 24^{\prime} \mathrm{W} 52^{\circ} 56^{\prime} \mathrm{N}$; Fig. 1). The Tern is a lowland catchment overlying the Permo-Triassic Sherwood Sandstone, which is occasionally overlain in the upper catchment by Rhaetian and Liassic clays and mudstones. Much of the catchment is farmed intensively; however, a study reach was identified that retains some valley bottom wetlands. Figure 2 summarises the logs of three boreholes drilled in the floodplain within $50 \mathrm{~m}$ of the wetland, to depths of $4 \mathrm{~m}, 10 \mathrm{~m}$ and $20 \mathrm{~m}$; these show that the local stratigraphy comprises a peat soil, red/brown sands and gravel, grading to a fine-grained red sandstone. Hence,

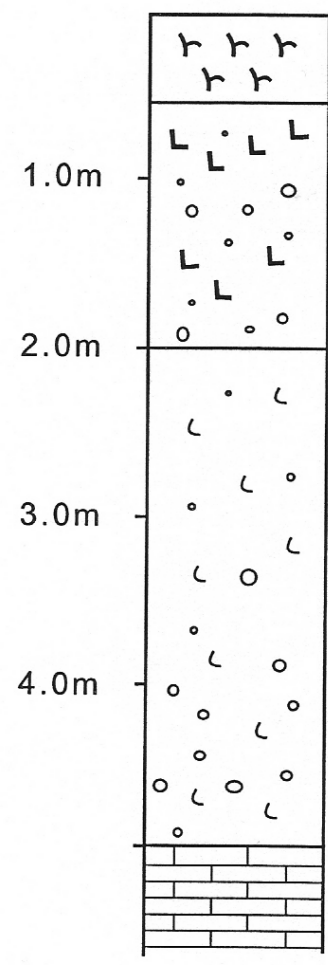

Peaty topsoil

Reddish brown, clayey

fine sand with

occasional gravel

Reddish brown, silty

clayey sand with

gravel and occasional

cobble

Brown to reddish brown fine to medium grained sandstone

Fig. 2. Detailed sedimentary profile at the borehole identified in Fig. 1, indicating the relationship of near-surface alluvial/organic deposits to the underlying Sherwood Sandstone. in the valley bottom, approximately $5 \mathrm{~m}$ of alluvial sediments overlie the Sherwood Sandstone. The mean annual flow of the Tern measured at a gauging station at Ternhill, $12 \mathrm{~km}$ downstream, is $0.82 \mathrm{~m}^{3} \mathrm{~s}^{-1}$, whilst mean annual precipitation is between 700 and $750 \mathrm{~mm}$.

The study site (Fig. 1) comprised a strip of land $200 \mathrm{~m}$ in length between the river and an access track to a sewage treatment works (STW). From the track, the land falls $5-10 \mathrm{~m}$ to the river and is marked by two small depressional wetlands. At the northern margin of the site, seepage springs emerge from the floodplain edge; a small spring also emerges in the southern portion of the wetland. Sampling nests comprising three ceramic suction probes were installed at depths of $0.2 \mathrm{~m}, 0.5 \mathrm{~m}$ and $1.0 \mathrm{~m}$ (Fig. 1) across the site to enable water samples to be extracted from the base, middle and top of the sedimentary profile (Hunt et al., 1998). Nests were positioned along two transects perpendicular to the river across each depressional wetland (A and $\mathrm{B})$, with an additional nest (C) at the downstream, southern, margin of the wetland. Five soil cores were extracted along each transect, from which five sub-samples were taken: at $0.05-$ $0.10 \mathrm{~m}$ from the surface and at four representative points through the profile. The organic matter content and inorganic particle size of the sub-samples were determined by losson-ignition and by laser particle spectrometry respectively. A schematic representation of these data is given in Fig. 3. Also shown in Fig. 3 are indicative saturated hydraulic conductivities (Ks); these were not measured in the field but are estimated from the particle size data following Rawls et al. (1982). Air temperature measured at the site, and mean daily precipitation observed at Audlem Mere Farm (SJ 692 410) and Willoughbridge (SJ 753 399), are given in Fig. 4. Monthly soil-water and end-member (atmospheric-, riverand spring-water) samples were collected between June 2000 and September 2001. Fieldwork was interrupted from March to May 2001 as a result of the foot-and-mouth outbreak, and sampling on Transect B ceased in February 2001. Bulk precipitation was collected using a funnelled vessel with a layer of medicinal paraffin to prevent evaporation, and are compared with monthly precipitation samples collected at Wallingford, c. $160 \mathrm{~km}$ to the SSE, by the British Geological Survey. River-water samples were taken from a mid-reach point and a spring-water sample was collected from a perennially flowing spring at the northern margin of the wetland. It was intended to install dipwells and tensiometer nests, but this was not possible as a result of vandalism.

Isotope samples were analysed using the equilibration method for oxygen (Epstein and Mayeda, 1953), and Znreduction method for hydrogen (Coleman et al., 1982; Heaton and Chenery, 1990). Isotopic ratios $\left({ }^{18} \mathrm{O} /{ }^{16} \mathrm{O}\right.$ and 


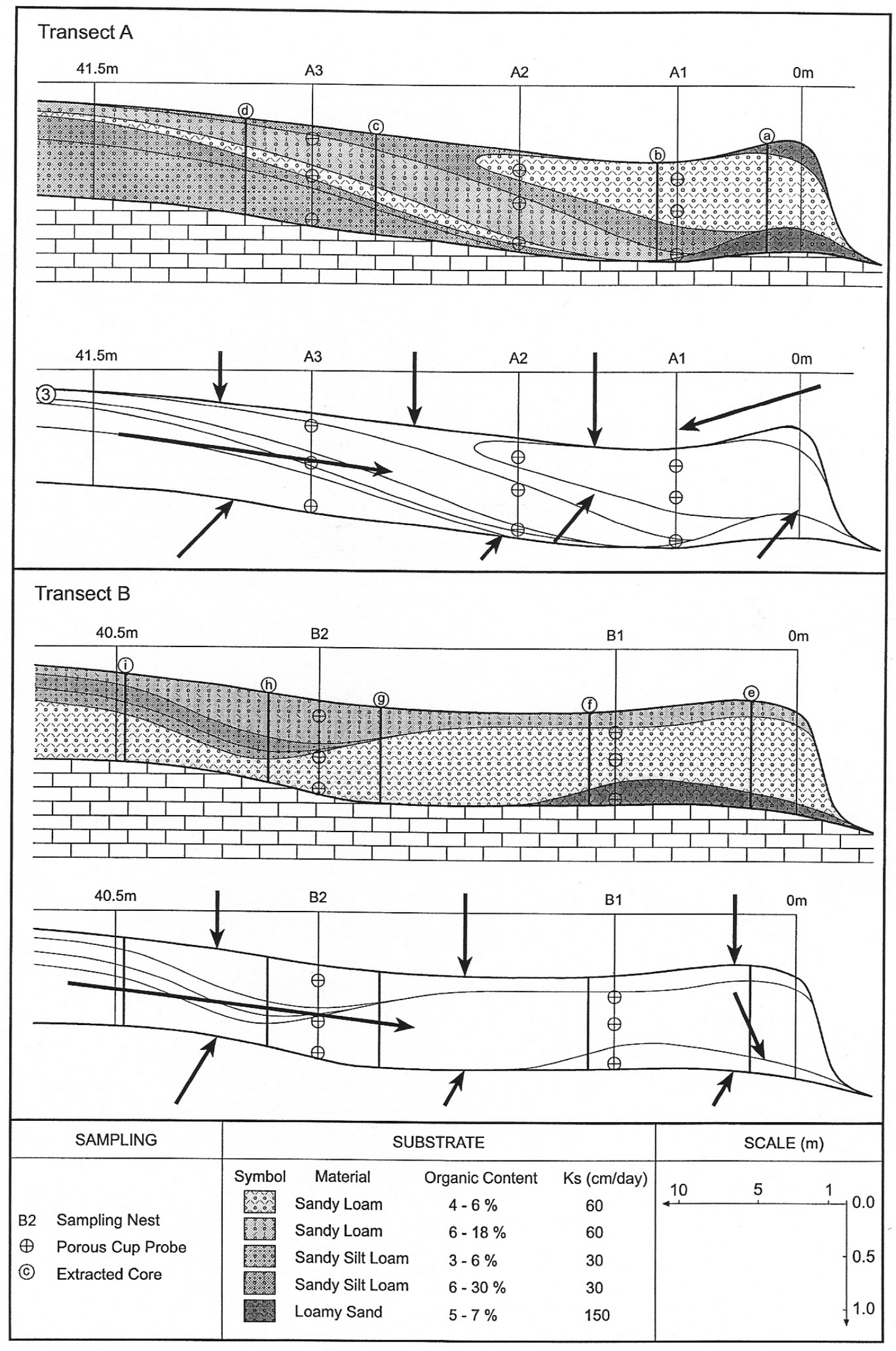

Fig. 3. Stratigraphic sections across Transects $A$ and B; with inferred water-pathways. 
$\left.{ }^{2} \mathrm{H} /{ }^{1} \mathrm{H}\right)$ are defined by their per mille difference from the international standard, V-SMOW (Vienna Standard Mean Ocean Water). Analytical precision is typically $\pm 0.05 \%$ of $\delta^{18} \mathrm{O}$ and $\pm 2.0 \%$ for $\delta^{2} \mathrm{H}$. The ${ }^{18} \mathrm{O} /{ }^{16} \mathrm{O}$ and ${ }^{2} \mathrm{H} /{ }^{1} \mathrm{H}$ ratios for two sets of samples in summer and winter 2000 were analysed to determine the local meteoric water line, whilst only ${ }^{18} \mathrm{O} /{ }^{16} \mathrm{O}$ were analysed for the remaining samples.

\section{Results}

Results of the stable isotope analysis on samples from Norton-in-Hales are shown in Figs. 4 and 5 with summary statistics in Table 1. Figure 6 gives the summer and winter local meteoric water lines (LMWL) based upon results from Norton-in-Hales and Wallingford. While the winter samples from Norton are comparable with the Wallingford record, the summer samples are more positive, indicating the preferential removal of the lighter isotope $\left({ }^{16} \mathrm{O}\right.$ and $\left.{ }^{1} \mathrm{H}\right)$ through evaporation.

\section{END-MEMBERS}

Fluctuations in the precipitation isotope ratio are associated with factors including the provenance and temperature of the rain-producing air mass and the amount of precipitation (Dansgaard, 1964). As a result, the isotope composition of rainfall tends to follow a distinct seasonal pattern in which winter precipitation is generally more depleted in ${ }^{18} \mathrm{O}$ than summer precipitation (Darling and Talbot, 2003).

Groundwater samples should be characterised by isotope compositions that reflect the amalgamation of recharge water signatures (Darling et al., 2003). The combination of long residence time and groundwater mixing produces a trend in isotope composition for groundwater at the Tern that remains relatively constant throughout the year. Groundwater samples extracted by the Environment Agency from a local borehole at Bloreheath (SJ 691 349; $4 \mathrm{~km}$ from the study site) showed a consistent trend with $\delta^{18} \mathrm{O}$ values of around $-7.9 \%$, and the mean $\delta^{18} \mathrm{O}$ value from Bloreheath is adopted as the groundwater end-member for this study. This figure
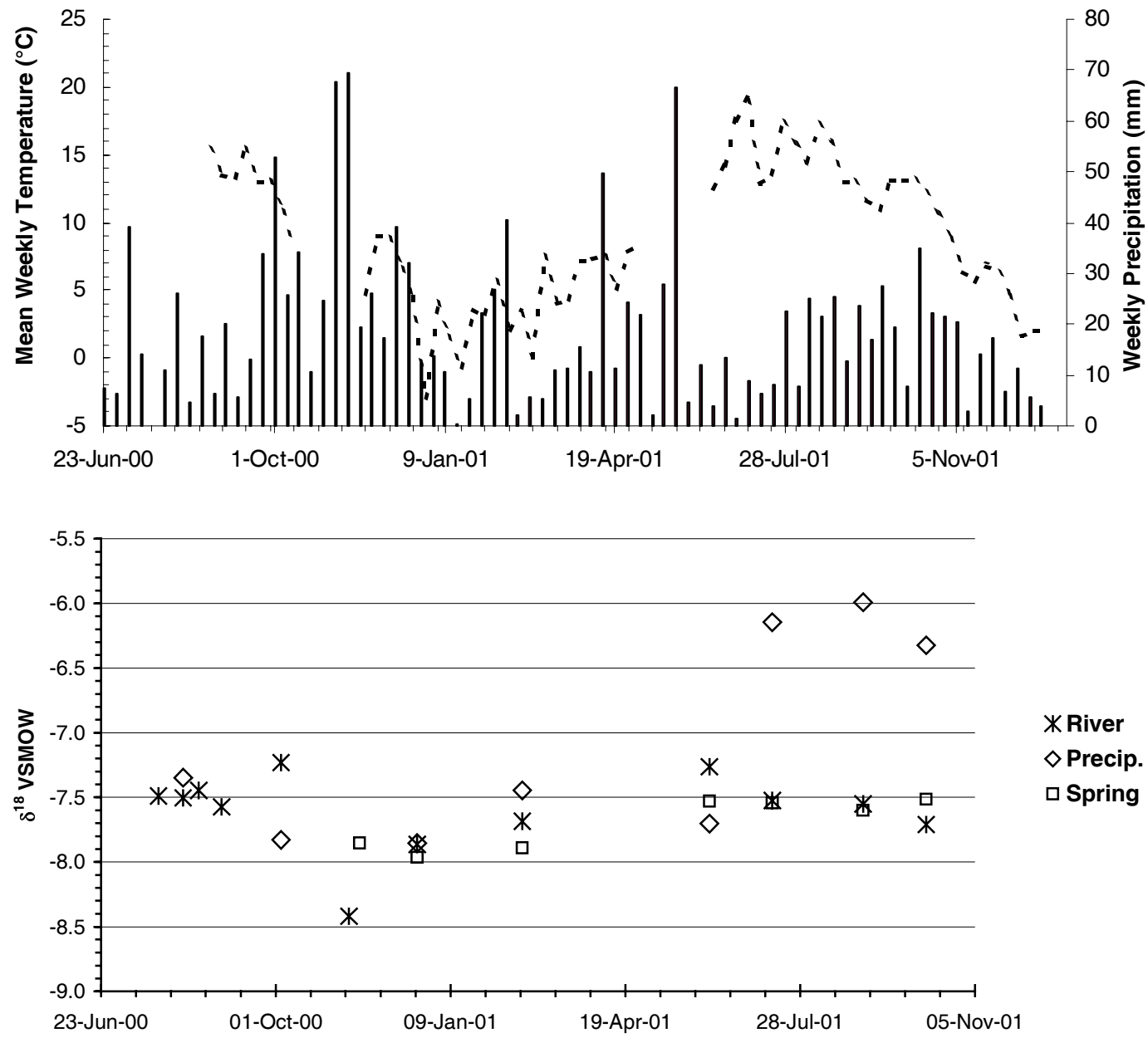

Fig. 4 Total weekly precipitation and mean weekly air temperature over the study period (top)and variation in $\delta^{I 8} O$ end-members (bottom). 

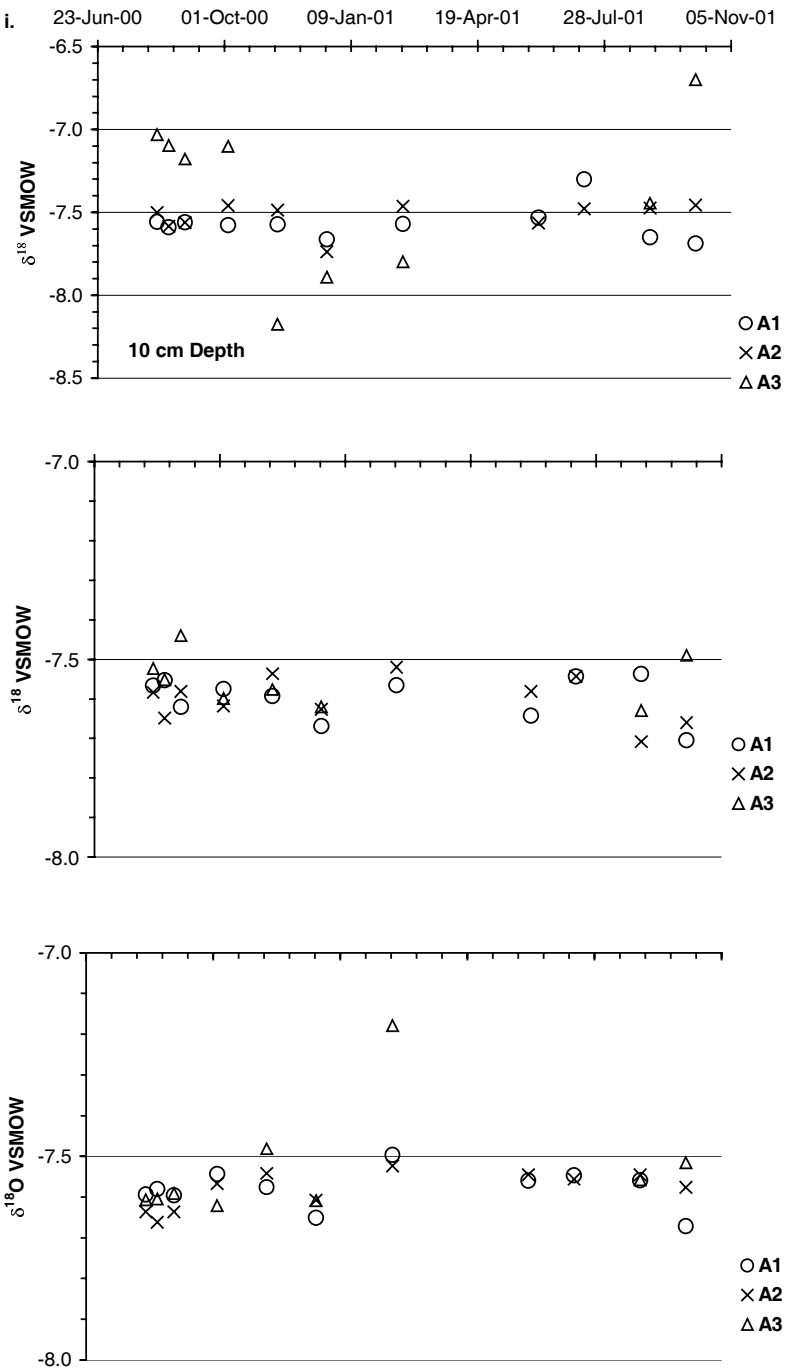
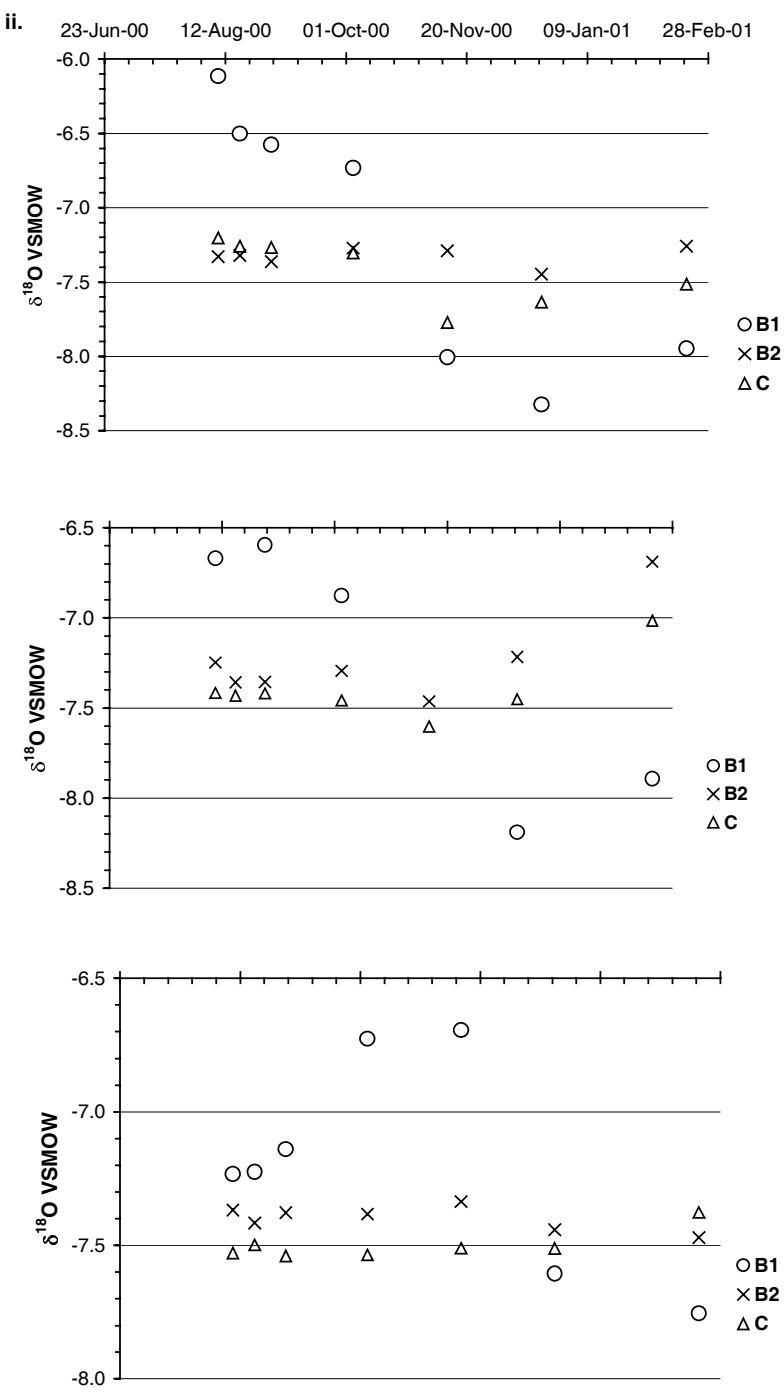

Fig. 5. Temporal variations in soil-water $\delta^{18} O$ composition along (i) Transect $A$ and (ii) Transect $B$ and Nest $C$.

is consistent with 24 groundwater samples extracted from boreholes in North Shropshire by the British Geological Survey in $1984\left(\delta^{18} \mathrm{O}\right.$ mean $-7.9 \%$, standard deviation $0.2 \%$; $\delta^{2} \mathrm{H}$ mean $51.3 \%$; standard deviation $1.5 \%$ ).

Surface-water sources to the wetland are limited to occasional episodes of overbank flooding in areas immediately beside the river. The isotope composition of the River Tern is relatively consistent, although it follows the atmospheric trend by being slightly higher in late autumn (04/10/00) and summer (06/06/01) (Fig. 4b). However, the relationship between the isotope composition of the Tern (surface-water sample) and precipitation varies seasonally. The isotope compositions of precipitation and river-water correspond closely in the period October 2000 - April 2001 and in October 2001, but differ markedly in the summer, when the river-water sample is considerably lower (riverwater sample $\delta^{18} \mathrm{O}$ of $-7.7 \%$ in July 2001, compared with $\delta 5.0 \%$ in precipitation). This suggests that, in summer, river base flows are largely sustained by groundwater seepage but that, in autumn and winter, the isotope composition may be depleted, reflecting the contribution of precipitation. Generally, however, the isotope ratios of the surface-water and groundwater samples are rather similar, which makes it difficult to isolate water inflow associated with these two sources.

\section{THE INFLUENCE OF SOIL STRATIGRAPHY ON WETLAND HYDROLOGY}

The sedimentary composition of the two Transects A and $B$, is shown in Fig. 3. The soils vary between a sandy loam and a sandy silt loam, with organic contents that are typically higher in the upper soil horizons distant from the river. Whilst the direction and rate of soil-water flow will be 
Table 1. Descriptive statistics for end-member and soil-water $\delta^{18} \mathrm{O}$ isotopic composition.

\begin{tabular}{|c|c|c|c|c|c|}
\hline Sample & No of Samples & Maximum & Mean & Minimum & Standard Deviation \\
\hline Winter Precipitation & 13 & $-6.0($ Sept 00$)$ & -7.1 & $-7.9(\operatorname{Dec} 00)$ & 0.8 \\
\hline Summer Precipitation & 13 & -6.2 (July 01) & -7.1 & -7.7 (June 01) & \\
\hline River Water & 13 & $-7.3($ Oct 00$)$ & -7.6 & -8.4 (Nov. 00) & 0.3 \\
\hline Springwater & 11 & $-7.5($ Oct 01$)$ & -7.7 & -8.0 (Dec. 00) & 0.2 \\
\hline $\begin{array}{l}\text { Soil Water }-\mathrm{A} 1 \\
0.2 \mathrm{~m} \\
0.5 \mathrm{~m} \\
1.0 \mathrm{~m}\end{array}$ & $\begin{array}{l}11 \\
11 \\
11\end{array}$ & $\begin{array}{l}-7.3 \text { (July 01) } \\
-7.5 \text { (July 01) } \\
-7.5 \text { (Feb 01) }\end{array}$ & $\begin{array}{l}-7.6 \\
-7.6 \\
-7.6\end{array}$ & $\begin{array}{l}-7.7 \text { (Oct. 01) } \\
-7.7 \text { (Oct. 01) } \\
-7.7 \text { (Oct. 01) }\end{array}$ & $\begin{array}{l}0.1 \\
0.1 \\
0.1\end{array}$ \\
\hline $\begin{array}{l}\text { Soil Water }-\mathrm{A} 2 \\
0.2 \mathrm{~m} \\
0.5 \mathrm{~m} \\
1.0 \mathrm{~m}\end{array}$ & $\begin{array}{l}11 \\
11 \\
11\end{array}$ & $\begin{array}{l}-7.5 \text { (Oct. 01) } \\
-7.5 \text { (Feb. 01) } \\
-7.5 \text { (Feb. 01) }\end{array}$ & $\begin{array}{l}-7.5 \\
-7.6 \\
-7.6\end{array}$ & $\begin{array}{l}-7.7 \text { (Dec. 00) } \\
-7.7 \text { (Sept. 00) } \\
-7.7 \text { (Aug. 00) }\end{array}$ & $\begin{array}{l}0.1 \\
0.1 \\
0.1\end{array}$ \\
\hline $\begin{array}{l}\text { Soil Water }-\mathrm{A} 3 \\
0.2 \mathrm{~m} \\
0.5 \mathrm{~m} \\
1.0 \mathrm{~m}\end{array}$ & $\begin{array}{l}9 \\
8 \\
9\end{array}$ & $\begin{array}{l}-6.7 \text { (Oct. 01) } \\
-7.4 \text { (Aug. 00) } \\
-7.2 \text { (Feb. 01) }\end{array}$ & $\begin{array}{l}-7.4 \\
-7.6 \\
-7.5\end{array}$ & $\begin{array}{l}-8.2 \text { (Nov. 00) } \\
-7.6 \text { (Sept. 01) } \\
-7.6 \text { (Oct. 00) }\end{array}$ & $\begin{array}{l}0.5 \\
0.1 \\
0.1\end{array}$ \\
\hline $\begin{array}{l}\text { Soil Water }-\mathrm{B} 1 \\
0.2 \mathrm{~m} \\
0.5 \mathrm{~m} \\
1.0 \mathrm{~m}\end{array}$ & $\begin{array}{l}7 \\
7 \\
7\end{array}$ & $\begin{array}{l}-6.1 \text { (Aug. 00) } \\
-6.4(\text { Aug 00) } \\
-6.7 \text { (Nov. 00) }\end{array}$ & $\begin{array}{l}-7.2 \\
-7.4 \\
-7.2\end{array}$ & $\begin{array}{l}-8.3 \text { (Dec. 00) } \\
-9.3 \text { (Nov. 00) } \\
-7.8 \text { (Feb. 01) }\end{array}$ & $\begin{array}{l}0.9 \\
1.1 \\
0.4\end{array}$ \\
\hline $\begin{array}{l}\text { Soil Water }- \text { B2 } \\
0.2 \mathrm{~m} \\
0.5 \mathrm{~m} \\
1.0 \mathrm{~m}\end{array}$ & $\begin{array}{l}7 \\
7 \\
7\end{array}$ & $\begin{array}{l}-7.3(\text { Feb } 01) \\
-7.2(\text { Dec } 01) \\
-7.3(\text { Nov } 00)\end{array}$ & $\begin{array}{l}-7.3 \\
-7.2 \\
-7.4\end{array}$ & $\begin{array}{l}-7.5 \text { (Dec. 00) } \\
-7.5 \text { (Nov. 00) } \\
-7.5 \text { (Feb. 01) }\end{array}$ & $\begin{array}{l}0.1 \\
0.3 \\
0.1\end{array}$ \\
\hline $\begin{array}{l}\text { Soil Water }-\mathrm{C} 1 \\
0.2 \mathrm{~m} \\
0.5 \mathrm{~m} \\
1.0 \mathrm{~m}\end{array}$ & $\begin{array}{l}11 \\
11 \\
11\end{array}$ & $\begin{array}{l}-7.2 \text { (Sept. 00) } \\
-7.0 \text { (Feb. 01) } \\
-7.4 \text { (Feb. 01) }\end{array}$ & $\begin{array}{l}-7.4 \\
-7.4 \\
-7.5\end{array}$ & $\begin{array}{l}-7.8 \text { (Nov. 00) } \\
-7.6 \text { (Nov. 00) } \\
-7.5 \text { (Aug. 00) }\end{array}$ & $\begin{array}{l}0.2 \\
0.2 \\
0.1\end{array}$ \\
\hline
\end{tabular}
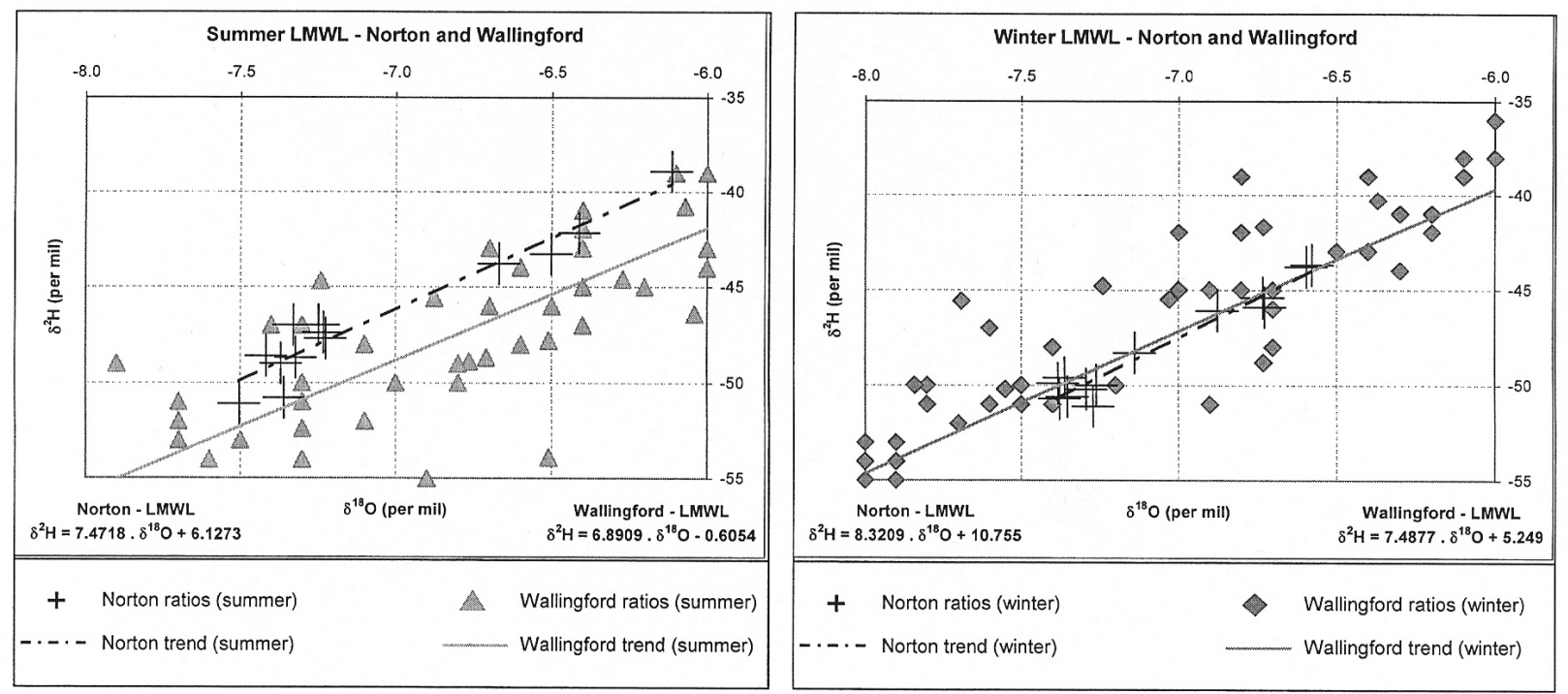

Fig. 6. The local meteoric water line compiled separately for summer and winter periods. 
determined by the local hydraulic gradient, the distribution of stratigraphic layers in each transect affects the potential for water storage and movement. Hypothetical water flow paths are illustrated in Fig. 3a, illustrating how water is likely to be derived from three distinct sources: precipitation, overbank river flows and groundwater. In the absence of hydraulic head data, the relative contribution of each water source cannot be determined; however, waters derived from precipitation should predominate near the surface, whilst following flood events, the river should be the main water source in the riparian zone, and could infiltrate the moderately permeable sandy loam. At deeper points in the cross-section, water will reflect the interaction between down-slope sub-surface seepage and upwelling groundwater. The soil profile for Transect B, shown in Fig. $3 \mathrm{~b}$, reveals a small depression near B2 in-filled with rich organic sandy loam sediments. This is likely to remain saturated as drainage is impeded by the underlying lower permeability sandy-silt layer.

In the absence of hydraulic head data, water samples collected manually from porous cup samplers were analysed to investigate whether variations in the isotopic composition enabled the seasonal pattern of water inflow to be determined across the two cross-sections.

\section{OBSERVED SOIL-WATER ISOTOPE COMPOSITIONS}

Variations in soil-water isotope composition across Transect $\mathrm{A}$ are given in Table 1, and compared with end-member data trends in Fig. 5. Isotope compositions at A1, A2 and A3 are relatively consistent through the study period and at different depths, suggesting that samples are derived mainly from a single water source. Minor variations in isotope composition near the surface $(0.2 \mathrm{~m}$ depth) are probably associated with individual precipitation events. This is particularly evident at $\mathrm{A} 3$ where the timing of enriched and depleted water samples $(-8.2 \%$ in November 2000 and $-6.7 \%$ in October 2001) follow the seasonal trend in precipitation. However, over the study period, the isotope compositions of most of the soil-water samples collected are comparable with samples collected from a spring adjacent to the wetland, suggesting that most soil-water samples from this transect are derived from groundwater.

In contrast, there is considerably more variation in the isotope compositions of samples collected from Transect B (Fig 5b). This is particularly evident in samples collected at $\mathrm{B} 1$, where the timing of maximum enrichment in $\delta^{18} \mathrm{O}$ (-6.1\%o at $0.2 \mathrm{~m}$ depth in August 2000) coincides with the seasonal pattern of enrichment in precipitation. This indicates that, at this point, waters are derived from recent precipitation, or local overbank flooding. There is also a considerable variability in isotope compositions at the three depths at B1 suggesting that, at this point, there are distinct differences in the source of water at different depths in the profile. Some of the differences might reflect the contact between groundwater (at $1.0 \mathrm{~m}$ depth) and summer precipitation (at the surface), but this might result from changes in the isotope composition between individual precipitation events. In any event, in B2 there is little variation between samples at each depth where the isotope composition is generally comparable with groundwater.

\section{Discussion}

Although the results described here are rather limited, in that only a small number of samples has been analysed over a relatively short period of time, the results demonstrate the degree to which wetland water sources may vary over comparatively short distances and time-scales, in what is apparently a small homogeneous wetland. In the literature, the temporal and spatial variations in the sources of water to wetlands have been relatively neglected, although differences in water source, particularly in the riparian zone, will determine both the water regime and nutrient availability.

Understanding the spatial and temporal dynamics of principal water inflows for many wetlands presents a considerable problem: in the context of the valley-side wetlands at Norton-in-Hales, it depends upon the interaction between regional groundwater flowpaths, hill-slope seepage, river flow and precipitation. Effectively, the transects investigated in this study beside the Tern comprise small wetland 'flushes' that extend over an incipient headwater floodplain, and the margins of the adjacent slopes. In this situation, groundwater is the main water inflow to the wetland but, under appropriate conditions, other water sources such as precipitation, may dominate. Clearly important also is the mechanism by which water moves through the hillslope, in ways that reflect variations in permeability (Weyman, 1973).

The isotope data confirm, as expected, that groundwater is the most important source of water to the wetland; however, under certain conditions, precipitation and riverwater can be important. Most water samples collected from the two main transects show little evidence of either summer enrichment or winter depletion following precipitation, indicating that both transects are largely dominated by groundwater, whether upwelling from the Sherwood Sandstone, or from the valley side.

However, point B1, adjacent to the river, represents a clear exception to this trend; at this point there is considerably more variation in the isotope ratios of samples extracted 
from the three different depths through 2000. For example, in August $2000 \delta^{18} \mathrm{O}$ varied from $-6.1 \%$ at $0.2 \mathrm{~m}$, to $-6.6 \%$ at $0.5 \mathrm{~m}$ and $-7.2 \%$ at $1.0 \mathrm{~m}$ depth; in October $2000 \delta^{18} \mathrm{O}$ at all three depths was $-6.7 \pm 0.1 \%$; while in November 2000 , $\delta^{18} \mathrm{O}$ was $-6.7 \%$ at $1.0 \mathrm{~m}$ depth, $-8.0 \%$ at $0.2 \mathrm{~m}$ depth and $-9.3 \%$ at $0.5 \mathrm{~m}$ depth. Thus in August the trend was for samples to become increasingly depleted with depth at B1, but in November there was no simple relationship with depth as the samples varied from being relatively enriched in $\delta^{18} \mathrm{O}$ at $1.0 \mathrm{~m}$ depth $(-6.7 \% \mathrm{o})$ to depleted at a depth of $0.5 \mathrm{~m} \mathrm{(-}$ $9.3 \%$ ). It seems that B1 is a relatively well-drained point and, in contrast to the other sites sampled, the water table is sufficiently low in summer for recent precipitation to represent an important water source. Water samples extracted from $0.2 \mathrm{~m}$ at $\mathrm{B} 1$ reflect the seasonal trend in precipitation and become increasingly depleted in the autumn and winter. However, the sample at $0.5 \mathrm{~m}$ depth is much lower in $\delta^{18} \mathrm{O}$ in November and, as river-water was also lower at this time, this may reflect precipitation from an unusually cold air mass in late October/early November which produced a distinctive isotope signature associated with a single rain event.

The results described in this paper have several implications for the study of wetland hydrology generally. While, for most wetlands, the relative importance of the different components of the annual water budget is understood, more work is required to quantify their spatial and temporal variability. Careful consideration must be given to the implications of local variability in hydrological processes, as demonstrated at Norton by the differences between points $\mathrm{A} 1$ and $\mathrm{B} 1$ adjacent to the river. Hunt et al. (1996) highlighted the difficulty in attempting to model wetland hydrology at a 'site scale'; there may also be considerable hydrological variability over comparatively small distances so that it may be difficult to identify 'representative' sample points.

Generally, however, the variation in the isotope data described here illustrates the potential of stable isotopes to clarify hydrological dynamics within a headwater lowland wetland. The combination of a seasonal trend in rain water isotope composition and a temporally consistent groundwater signature demonstrates the relative importance of precipitation and groundwater contributions to different parts of the wetland. Discrimination of wetland water sources is dependent upon whether discrete compositions occur and it is important to acquire a temporally specific end-member data set (i.e. atmospheric, ground- and surfacewater). However, the paper shows the extent to which wetland water sources may vary seasonally over comparatively short distances and demonstrates the importance of determining the stratigraphy of the site.

\section{Acknowledgements}

The authors would like to thank Carol Arrowsmith (NIGL) for the stable isotope analysis, Kevin Burkhill and Anne Ankcorn for cartography, and the British Atmospheric Data Centre, the Environment Agency and BGS Wallingford for additional data. This research was supported by AC's NERC research studentship, and by additional funding from NIGFSC (IP/680/0301).

\section{References}

Bradley, C., 1997. The hydrological basis for conservation of floodplain wetlands: implications of work at Narborough Bog, UK. Aquat. Conserv. 7, 41-62.

Bradley, C., 2002. Simulation of the annual water table dynamics of a floodplain wetland, Narborough Bog, UK. J. Hydrol., 261, $150-172$.

Coleman, M.L., Shepherd, T.J., Durham, J.J., Rouse, J.E. and Moore, G.R., 1982. Reduction of water with zinc for hydrogen isotope analysis. Anal. Chem., 54, 993-995.

Cooper, D.J., MacDonald, L.H., Wenger, S.K. and Woods, S.W., 1998. Hydrologic restoration of a fen in Rocky Mountain National Park, Colorado, USA. Wetlands, 18, 335-345.

Dansgaard, W., 1964. Stable isotopes in precipitation. Tellus, 16, 436-468.

Darling, W.G. and Talbot, J.C., 2003. The O \& H stable isotope composition of fresh waters in the British Isles. 1. Rainfall. Hydrol. Earth Syst. Sci., 7, 163-181.

Darling, W.G., Bath, A.H. and Talbot, J.C., 2003. The O \& H stable isotope composition of fresh waters in the British Isles. 2. Surface waters and groundwater. Hydrol. Earth Syst. Sci., 7, 183-195.

Drexler, J.Z., Bedford, B.L., DeGaetano, A.T. and Siegel, D.I., 1999. Quantification of the water budget and nutrient loading in a small peatland. J. Amer. Water Res. Assoc., 35, 753-769.

Epstein, S. and Mayeda, T., 1953. Variation in ${ }^{18} \mathrm{O}$ content of waters from natural sources. Geochim. Cosmochim. Acta, 4, 213-224.

Heaton, T.H.E. and Chenery, C.A., 1990. Use of zinc turnings in the reduction of water to hydrogen for isotopic analysis. NERC Isotope Geoscience Laboratory Report 24. Nottingham, UK.

Hill, A.R. and Waddington, J.M., 1993. Analysis of storm runoff sources using oxygen-18 in a headwater swamp. Hydrol. Process., 7, 305-316.

Huddart, P.A., Longstaffe, F.J. and Crowe, A.S., 1999. $\delta$ D and $\delta^{18} \mathrm{O}$ evidence for inputs to groundwater at a wetland coastal boundary in the southern Great Lakes region of Canada. $J$. Hydrol., 214, 18-31.

Hunt, R.J., Krabbenhoft, D.P. and Anderson, M.P., 1996. Groundwater inflow measurements in wetland systems. Water Resour. Res, 32, 3, 495-507.

Hunt, R.J., Krabbenhoft, D.P. and Anderson, M.P., 1997. Assessing hydrogeochemical heterogeneity in natural and constructed wetlands. Biogeochemistry, 39, 271-293.

Hunt, R.J., Bullen, T.D., Krabbenhoft, D.P. and. Kendall, C., 1998. Using stable isotopes of water and strontium to investigate the hydrology of a natural and constructed wetland. Ground Water, 36, 434-443.

Matsuo, S. and Friedman, I., 1967. Deuterium content in fractionally collected rainwater. J. Geophys. Res., 72, 63746376.

Owen, C.R., 1995. Water budget and flow pattern in an urban wetland. J. Hydrol., 169, 171-187. 
Rawls, W.J., Brakensiek, D.L. and Saxton, K.E., 1982. Estimating soil water properties. Trans. ASAE, 25, 1316-1320 and 1328.

Soulsby, C., Malcolm, R., Helliwell, R., Ferrier, R.C. and Jenkins, A., 2000. Isotope hydrology of the Allt a' Mharcaidh catchment, Cairngorms, Scotland: implications for hydrological pathways and residence times. Hydrol. Process., 14, 747-762.

Waddington, J.M., Roulet, N.T. and Hill, A.R., 1993. Runoff mechanisms in a forested groundwater discharge wetland. $J$. Hydrol., 147, 37-60.
Weyman, D.R., 1973. Measurements of the downslope flow of water in a soil. J. Hydrol. 20, 267-288.

Winter, T.C., 1999. Relation of streams, lakes and wetlands to groundwater flow systems. Hydrogeol. J., 7, 28-45.

Zeeb, P.J. and Hemond, H.F., 1998. Hydrologic response of a wetland to changing moisture conditions: modelling effects of soil heterogeneity. Climatic Change, 40, 211-227. 